\title{
A Descriptive Study of Covid-19: Risk Perception and Preventive Behavior in West Java, Banten and Jakarta
}

\author{
Putri Permatasari ${ }^{1}$, Chahya Kharin Herbawani ${ }^{1, *}$, Ulya Qoulan Karima ${ }^{1}$, Arnur \\ Oktafiyanti $^{1}$, Nadia Ramadhanty ${ }^{1}$ \\ ${ }^{1}$ Faculty of Health, UPN Veteran Jakarta \\ ${ }^{*}$ Corresponding author. Email: chahyakharin@upnvj.ac.id
}

\begin{abstract}
Background: Coronavirus disease 2019 (COVID-19) caused by SARS-CoV-2 recently became a global pandemic. Covid-19 can spread from person to person through tiny droplets from the nose or mouth (droplets) that spread through the air when someone with Covid-19 coughs, sneezes, speaks, and exhale. This study identified risk perception and preventive behavior of Covid-19. Risk perception of COVID-19 is the main determinant of practicing protective behaviors. Methods: This study was descriptive, using a cross-sectional survey in Indonesia. The population of this study was all residents in Jakarta, Bogor, Depok, Tangerang, and Bekasi. Inclusion criteria were minimum 18 years old and able to fill out an online questionnaire since this study was an online survey-based. Results: This study collected 513 questionnaires filled out online. After filtering, the data obtained from only 448 questionnaires could be processed. About $44,5 \%$ of respondents confident that their chance to get infected by Covid-19 is low. Data showed that more than half of the respondents $(83,2 \%)$ very confident that they can be treated if they get infected by covid-19. Some of them $(6,3 \%)$ also said that they didn not use a mask if they have to go outside of the house. Conclusion: The study concluded that the community still has no enough risk perception and inadequate protective behaviors to prevent COVID-19. The community needs to be informed about the potential risks of infection to adopt the right precautionary measures.
\end{abstract}

\section{Keywords: COVID-19, Risk Perception, Preventive Behavior}

\section{INTRODUCTION}

WHO declared Covid-19 as an infectious disease caused by the most recently discovered Coronavirus. This new virus and disease first discovered in Wuhan, China, in December 2019. Covid-19 can spread from person to person through tiny droplets from the nose or mouth (droplets) that spread through the air when someone with Covid-19 coughs, sneezes, speak and exhale. Droplets can stick to objects or other surfaces such as tables, door handles and other surfaces. So that people can also be infected with the virus if they touch these objects or surfaces, then touch their eyes, nose or mouth [1].

As of October 7, 2002, the number of Covid-19 cases reached 35,347,404 people throughout the world, including Indonesia. The total number of deaths in the world due to this disease has reached $1,039,406$ people with a mortality rate of $2.9 \%$. In Indonesia on October 7, 2020, the number of Covid-19 cases had reached 315,714 with 11,472 deaths, and 240,291 cases declared cured. Among the 34 provinces in Indonesia, DKI Jakarta is still the province with the highest number of confirmed Covid-19 cases. As of October 4, 2020, DKI Jakarta is known to have had 78,850 people confirmed as Covid-19, as many as 64,229 cases were declared cured and as many as 1,755 cases died. Besides, on the same date, the number of confirmed cases of Covid19 in West Java was 23,899, 14,137 people were declared cured, and 480 people died. Then in Banten, the number of Covid-19 cases until October 7 reached 6,129 confirmed cases, 4,382 cases recovered, and 184 deaths [2].

In the current era of digitalization, it is easy for Indonesian people to access various information. The circulation of information related to Covid-19 in various types of media has triggered the emergence of various perceptions in public about Covid-19, one of which is the risk perception of Covid-19. Perception of risk is a form of interpretation or assessment of risky situations based on the experiences or beliefs they have [3]. Perceptions of risk can be influenced 
by several factors, including cultural factors, socioeconomic background, affective, cognitive, personality, anxiety, and behavior.

Perceptions of risk play an essential role in a person's decisions in determining risk management or prevention behavior, for example, vaccinations, washing hands, wearing seat belts, and early screening for other diseases. The public's risky perception of Covid-19 is indicated as one of the factors contributing to increasing public

\section{METHODS}

This study was descriptive, using a cross-sectional survey in Indonesia. The population of this study was all residents in Jakarta, Bogor, Depok, Tangerang, and Bekasi. Inclusion criteria were minimum of 18 years old and able to fill out an online questionnaire since this study was an online survey-based. Exclusion criteria were refused to participate and invalid questionnaire filling. The sample was recruited through purposive sampling as they meet the inclusion and exclusion criteria.

The variables of this study were: socio-demographic, risk perception and preventive behavior of Covid-19. An onlineadministered structured questionnaire was used to collect information on these variables from Agustus- September 2020. The descriptive analysis were applied in term of distribution and frequencies on each variable. Health Research Etic Committee of the institution, with participation in adopting Covid-19 prevention measures. Therefore, if the public does not have a risk perception and I or cannot control the perception of risk, it will lead to a lack of community participation in efforts to prevent Covid19 so that it can lead to an increase in Covid-19 cases in Indonesia.

Therefore, this study aimed to identify risk perception and behavior towards the prevention of Covid-19 transmission in West Java, Banten and Jakarta.

regard to protection of human rights and welfare in medical research, had carefully reviewed this study and approved it.

\section{RESULTS}

This study collected 513 questionnaires filled out online. After filtering, the data obtained from only 448 questionnaires could be processed. Respondents came from 3 provinces out of 34 provinces in Indonesia. Most of them (45.5\%) were from DKI Jakarta Province. Over half of the respondents were aged 18-25 years (60\%). Based on education level, $53.5 \%$ of the respondents were senior high school graduates. As many as $46.3 \%$ of the respondents were college students. In terms of marital status, $50.09 \%$ of them were unmarried/single. The socio-demographic characteristics of the respondents are shown in Table 1.

Table 1 Characteristics of Respondents

\begin{tabular}{|c|c|c|c|c|c|c|}
\hline Variable & \multicolumn{2}{|l|}{$\begin{array}{r}\text { Category } \\
(488) \\
\end{array}$} & \multirow[t]{2}{*}{$\%$} & Category & \multicolumn{2}{|l|}{$\begin{array}{l}\% \\
\quad(488) \\
\end{array}$} \\
\hline Socio- & Province & & & Housewife & 27 & 5.5 \\
\hline \multirow[t]{15}{*}{ Demographic } & DKI Jakarta & 222 & 45.5 & Pensionary & 1 & 0.2 \\
\hline & Jawa Barat & 200 & 41.0 & Non-profit institution & 1 & 0.2 \\
\hline & Banten & 66 & 13.5 & Unemployed & 14 & 2.9 \\
\hline & Age $^{a}$ & & & Others & 48 & 9.8 \\
\hline & $18-25$ years & 293 & 60.0 & Education & & \\
\hline & $26-35$ years & 94 & 19.3 & No education & 1 & 0.2 \\
\hline & $36-45$ years & 58 & 11.9 & Primary school & 3 & 0.6 \\
\hline & $46-55$ years & 22 & 4.5 & Junior high & 6 & 1.2 \\
\hline & $56-65$ years & 4 & 8 & Senior high & 261 & 53.5 \\
\hline & $>65$ years & 1 & 2 & Bachelor & 154 & 31.6 \\
\hline & Occupation & & & Postgraduate & 59 & 12.1 \\
\hline & Civil Service Staff & 53 & 10.9 & Doctoral & 4 & 0.8 \\
\hline & Private sector & 96 & 19.7 & & & \\
\hline & Private enterprise & 16 & 3.3 & & & \\
\hline & College student & 226 & 46.3 & & & \\
\hline
\end{tabular}

This study used online questionnaires, so it only reached respondents who have access to technology and understand how to fill out questionnaires online. Although this presented a limitation to this study, online questionnaires are quick and convenient to use. In the future, another study could use hard-printed questionnaires to reach other respondents who cannot use technology.

\section{Respondents' Risk Perception}

Table 2 describes perceived susceptibility to COVID-19 among the respondents. About $44,5 \%$ of respondents confident that their chance to get infected by Covid-19 are low and very low. More than half of them $(83,2 \%)$ very confident that they can be treated if they get infected by covid-19. 
Table 2Risk Perception

\begin{tabular}{|c|c|c|c|c|c|c|}
\hline Variable & $\begin{array}{lr}\text { Category } & \begin{array}{r}N \\
(488)\end{array} \\
\end{array}$ & & $\%$ & $\mathrm{~N} \quad \%$ & \multicolumn{2}{|l|}{ (488) } \\
\hline Risk & Chance to get infection of COVID-19 & & & Chance to get infection & & \\
\hline \multirow[t]{33}{*}{ Perception } & Very low & 61 & 12.5 & When Going Some Celebration & & \\
\hline & Low & 156 & 32.0 & Very low & 14 & 2.9 \\
\hline & Moderate & 177 & 36.3 & Low & 27 & 5.5 \\
\hline & High & 68 & 13.9 & Moderate & 95 & 19.5 \\
\hline & Very high & 26 & 5.3 & High & 197 & 40.4 \\
\hline & Chance to get infection & & & Very high & 155 & 31.8 \\
\hline & for the closest people & & & Chance to get infection & & \\
\hline & Very low & 57 & 11.7 & In Public Transportation & & \\
\hline & Low & 136 & 27.9 & Very low & 13 & 2.7 \\
\hline & Moderate & 169 & 34.6 & Low & 20 & 4.1 \\
\hline & High & 93 & 19.1 & Moderate & 84 & 17.2 \\
\hline & Very high & 33 & 6.8 & High & 176 & 36.1 \\
\hline & Chance to get infection & & & Very high & 195 & 40.0 \\
\hline & In The Neighborhood & & & Chance to get infection & & \\
\hline & Very low & 45 & 9.2 & In Work Place & & \\
\hline & Low & 116 & 23.8 & Very low & 33 & 6.8 \\
\hline & Moderate & 181 & 37.1 & Low & 83 & 17.0 \\
\hline & High & 103 & 21.1 & Moderate & 169 & 34.6 \\
\hline & Very high & 43 & 8.8 & High & 141 & 28.9 \\
\hline & Chance to get infection & & & Very high & 62 & 12.7 \\
\hline & When Going to The Market & & & How Many People Do You Know Who & & \\
\hline & Very low & 8 & 1.6 & Who Infected by COVID-19 & & \\
\hline & Low & 31 & 6.4 & Nothing & 300 & 61.5 \\
\hline & Moderate & 116 & 23.8 & 1 person & 59 & 12.2 \\
\hline & High & 203 & 41.6 & 2 persons & 47 & 9.6 \\
\hline & Very high & 130 & 26.6 & 3 persons & 21 & 4.3 \\
\hline & Chance to get infection & & & $>3$ persons & 61 & 12.5 \\
\hline & When Going to Work, School, College & & & How Sure Are You Going to Get Well & & \\
\hline & Very low & 19 & 3.9 & If You Are Infected by COVID-19 & & \\
\hline & Low & 54 & 11.1 & Not Sure & 13 & 2.7 \\
\hline & Moderate & 160 & 32.8 & Probably & 69 & 14.1 \\
\hline & High & 171 & 35.0 & Sure & 186 & 38.1 \\
\hline & Very high & 84 & 17.2 & Very Sure & 220 & 45.1 \\
\hline
\end{tabular}

\section{Respondents' Preventive Behavior}

Among 488 participants who heard about COVID-19, their reported protective behaviors were as follow: $34,6 \%$ wash hands very often, $6,1 \%$ avoided travel or trip, about $56,8 \%$ always completely cover the mouth and nose during coughing and sneezing and 70,7\% always use a mask when going outside the house (Table 3 ).

Table 3 Protective Behavior

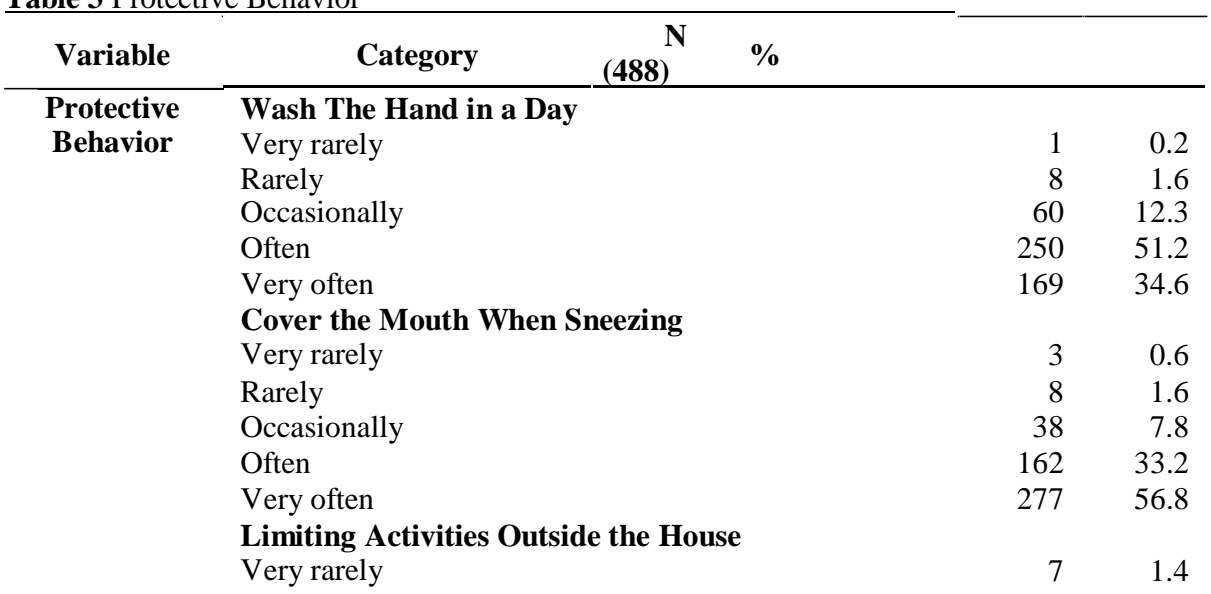




$\begin{array}{lrr}\text { Rarely } & 23 & 4.7 \\ \text { Occasionally } & 96 & 19.7 \\ \text { Often } & 227 & 46.5 \\ \text { Very often } & 135 & 27.7 \\ \text { Use a Mask When Go Outside the House } & & \\ \text { Rarely } & 28 & 0.6 \\ \text { Occasionally } & 112 & 23.7 \\ \text { Often } & 345 & 70.7 \\ \text { Very often } & & \\ \text { Physical Distancing When Go Outside the House } & 2 & 0.4 \\ \text { Very rarely } & 11 & 2.3 \\ \text { Rarely } & 67 & 13.7 \\ \text { Occasionally } & 196 & 40.2 \\ \text { Often } & 212 & 43.4 \\ \text { Very often } & & \\ \text { Do Not Touch Objects Outside the House } & 3 & 0.6 \\ \text { Very rarely } & 21 & 4.3 \\ \text { Rarely } & 119 & 24.4 \\ \text { Occasionally } & 197 & 40.4 \\ \text { Often } & 148 & 30.3 \\ \text { Very often } & & \\ \text { Check Body Temperature Routinely } & 39 & 8.0 \\ \text { Very rarely } & 95 & 19.5 \\ \text { Rarely } & 186 & 38.1 \\ \text { Occasionally } & 115 & 23.6 \\ \text { Often } & 53 & 10.9 \\ \text { Very often } & & \end{array}$

\section{DISCUSSIONS}

Risk perceptions refer to people's intuitive evaluations of hazards that they are or might be exposed to[4], including a multitude of undesirable effects that people associate with a specific cause. Risk perception of COVID-19 is the primary determinant of practising protective behaviors [5].

Higher COVID-19 knowledge was related to more excellent risk perception and more excellent precautionary behavior. Higher risk perception was related to more excellent precautionary behavior[5]. The result of this study showed that about $44,5 \%$ of respondents confident that their chance to get infected by Covid-19 are low and very low. Some of the respondents wrongly perceived that all of them had little chance to get the disease. Another study by Chahya Kharin Herbawani and Dadan Erwandi (2019) [5], produced similar things where lack of knowledge also cause negative risk perceptions. The result showed that when someone is ignorant against preventive behavior supposed to do.

In this study, it can be caused because some respondents do not understand the transmission of COVID-19. Distrust in COVID-19 can also be the result of why this is happening. When a person does not have a perception of the possibility of being infected by COVID-19, this can affect decision making in carrying out preventive behavior. If they do not have a perception that they may be infected with COVID-19, then they will also not follow the health protocols.

From 10 questions regarding risk perception (Table 2), $40,0 \%$ respondents answered that possibility of contracting COVID-19 in public transportation was very high, and only $8.8 \%$ respondents answered that possibility of contracting COVID-19 in the neighbourhood were very high. Almost half of the respondents $(45.1 \%)$ answered that they were very sure to get well if COVID-19 infected them. From this aspect, we could say that the respondent assumes that COVID-19 is an easily curable disease.

Compared to Mya et al. (2020) [5], 91\% of respondents agreed/strongly agree that they would quickly get disease in a crowded area. $86 \%$ of respondents were answered agree/strongly agree that if they were infected with COVID-19, they would suffer severe symptoms. $78 \%$ of respondents agreed/strongly agree if they were infected with COVID-19, they could not survive. $73 \%$ of respondents agreed/strongly agree that they can suffer from COVID-19 without signs and symptoms. $39 \%$ of respondents agreed/strongly agree that COVID-19 can be treated if they were infected. Only $11 \%$ of respondents agreed/strongly agree that if they were infected with COVID-19, they would recover spontaneously. 
Compared to Abdelrahman (2020) [7], the study of traits, risk perception, and protective behaviors of Arab residents of Qatar during the COVID-19 pandemic, $48.4 \%$ respondents answered that the danger of COVID-19 was perilous [7]. From this comparison, we could say that the present study revealed that there was a low-risk perception of how severe is COVID-19.

Iorfa et al.'s [8] study suggested that among women, being older (older) was associated with higher knowledge of COVID-19 and higher precautionary behavior, but not perceived risk. However, for males, being older (older age) was related to higher COVID19 knowledge, higher risk perception, and higher precautionary behavior[8].

Data showed that more than half of the respondents $(83,2 \%)$ very confident that they can be treated if they get infected by covid-19. Not all of the respondents understand that people who are aged over 60 years, and people who have underlying medical conditions such as diabetes, heart disease, respiratory disease or hypertension are among those who are at greater risk of developing severe or critical illness if infected with the virus[9]. It is also related to knowledge of covid19.

From 7 questions regarding protective behavior (Table 3 ), we could say that the best protective behavior was in use a mask because $70.7 \%$ respondents were very often to use a mask when going outside the house. However, only $10.9 \%$ of respondents were very often to check body temperature routinely. $34.6 \%$ of respondents were very often to wash the hand in a day. $27.7 \%$ of respondents were very often to limit activities outside the house. $43.4 \%$ of respondents were very often to do physical distancing when going outside. $30.3 \%$ of respondents

\section{CONCLUSION}

The study concluded that the community still has no enough risk perception and inadequate protective behaviors to prevent COVID-19. Community need to be informed about the potential risks of infection in order to adopt the right precautionary measures.

\section{ACKNOWLEDGMENT}

Our deepest appreciation goes to the UPN Veteran Jakarta for initiation and support in conducting this research project. We are very grateful to UPN Veteran Jakarta for

\section{REFERENCES}

[1]. WHO. Situation Report-49 Situation in Number total and new cases in last 24 hours. (2020) were very often to do not touch objects outside the house.

Compared to Mya, et al. (2020) [5]., the study of awareness, perceived risk and protective behaviors of Myanmar adults on COVID-19, 44.9\% respondents were washed hand for $>5$ times, $47.3 \%$ were always cover mouth and nose entirely during coughing and sneezing, $33.8 \%$ were avoiding to travel or trip, $57.9 \%$ were avoiding crowded area [5].

The present study was carried out with a crosssectional study. It brings advantages because it is suitable for estimating the prevalence of each variable. However, there might be selection bias since the nonrandom sampling methods used in this study, so we have to carefully interpret the findings to be generalized in Jakarta, Bogor, Depok, Tangerang, and Bekasi. Information bias might affect this study since this is an online-administered questionnaire that we could not control precisely how respondents fill the questionnaire.

The measure of risk perception was not an easy way. Risk is commonly understood as a cognitive evaluation of outcome probability and outcome severity. However, well known that people mostly ignore probability and mainly rely on outcome severity when judging risk. It is a bias known as probability neglect. Probability neglect leads people to overestimate the risk of dreadful events with small probabilities and to underestimate the risk of mundane events with higher probabilities[10].
Measures to control future outbreaks should not be limited to the development of vaccines, but also adequately informing the public about the comprehensive COVID-19 knowledge as well as risks since these have shown to be predictors of precautionary behavior. financial support through this paper. Last but not least, we would like to express our thanks to students and faculty members of Health Sciences for their active participation in data collection and respondents of this study for their enthusiastic involvement in answering the survey questions.

[2]. Kawal Covid. No Title [Internet]. Available from: https://kawalcovid19.id/ (2020) 
[3]. Paul Slovic. The Perception of Risk. University of Oregon Slovic. 2000

[4]. Rohrmann B. Risk Perception, Risk Attitude, Risk Communication, Risk Management: A Conceptual Appraisal. In: nternational Emergency Management Society Annual Conference, Prague, Czech Republic, 17-19 June 2008. (2008)

[5]. Mya KS, S. M. A, Hlaing WA, Hlaing SS, Aung T, Lwin SMM, et al. Awareness, perceived risk and protective behaviors of Myanmar adults on COVID-19. Int J Community Med Public Heal. 2020;7(5):1627. (2020)

[6]. Kharin Herbawani C, Erwandi D. Factors Associated with Human Immunodeficiency Virus (HIV) Prevention Behavior by Housewife in Nganjuk, East Java. J Kesehat Reproduksi. 2019;10(2):89-99(2019)
[7]. Abdelrahman M. Personality Traits, Risk Perception, and Protective Behaviors of Arab Residents of Qatar During the COVID-19 Pandemic. Int J Ment Health Addict (2020)

[8]. Iorfa SK, Ottu IFA, Oguntayo R, Ayandele O, Kolawole SO, Gandi JC, et al. COVID-19 knowledge, risk perception and precautionary behavior among Nigerians: A moderated mediation approach. medRxiv. (2020)

[9]. WHO. Coronavirus Disease Situation Report World Health Organization. World Health Organization. ;19(May):1-17. (2020)

[10]. K. Wolff, S. Larsen, T. Ogaard. How to measure risk perceptions. Elsevier (2019) 